\title{
Triple Class HIV-1 Drug Resistance in Croatia: the First Report
}

\author{
Ana Planinić ${ }^{1}$, Maja Oroz ${ }^{2}$, Snježana Židovec Lepej ${ }^{1}$ \\ ${ }^{1}$ Department of Immunological and Molecular Diagnostics, University Hospital for Infectious Diseases “Dr. Fran Mihalje- \\ vic", Zagreb, Croatia \\ ${ }^{2}$ University of Zagreb School of Medicine, Zagreb, Croatia
}

OPEN ACCESS

Correspondence:

Ana Planinić, PhD anaplaninic@yahoo.com

This article was submitted to RAD CASA - Medical Sciences as the original article

Conflict of Interest Statement: The authors declare that the research was conducted in the absence of any commercial or financial relationships that could be construed as a potential conflict of interest.

Received: 03 November 2019 Accepted: 28 November 2019 Published: 17 December 2019

Citation: Planinc A, Oroz M and Zidovec Lepej S. Triple class HIV-1 drug resistance in Croatia: the first report. RAD CASA - Medical Sciences. $540=48$ 49 (2019): 3-7. https: //dx.doi.
(20rg/10.21857/most org/10.21857/m16wjc6169
or 160 .

Copyright (C) 2019 Planinc, Oroz and Zidovec. This is an open-access article distributed under the terms of the Creative Commons Attribution License (CC BY). The use, distribution or reproduction in other forums is permitted, provided the original author(s) and the copyright owners(s) are credited and that the original publication in this journal is cited, in accordance whit accepted adacemic practice. whit accepted adacemic practice. No use, distribution or reproduction with these terms.

\section{ABSTRACT:}

Resistance of Human Immunodeficiency Virus (HIV) to antiretroviral drugs is an important limitation in achieving complete suppression of viral replication and therefore represents an important clinical issue. It refers especially to therapy-naive individuals infected with resistant HIV strains, e.g. individuals with transmitted drug resistance (TDR). Transmitted drug resistance mutations (TDRMs) are clinically relevant and may reduce the efficacy of antiretroviral therapy. In this paper, we report the first case of HIV-1 transmitted triple-class drug resistance in Croatia. The aim of this study was to characterize drug resistance patterns and TDRMs in the newly diagnosed, treatment-naive HIV-1 patient with such a complex resistance pattern. Sanger sequencing (SS) of the sample showed four reverse transcriptase inhibitor (RTI) resistance mutations (E44D, T215E, K103N, L100I) affecting two drug classes and two protease inhibitor resistance mutations (V32I, I47V). To characterize HIV-1 minority drug resistance variants below the detection limit of SS, deep sequencing (DS) analysis was performed. DS analysis identified the same triple class resistance pattern that was identified by SS with addition of several other RTI mutations. The patient described in this report is the first patient with HIV-1 triple-class resistance in Croatia and further studies will be directed toward analysing possible local onward transmission of this resistant virus.

KEYWORDS: HIV; Transmitted drug resistance (TDR); Sanger sequencing (SS); Deep sequencing (DS)

\section{SAŽETAK:}

REZISTENCIJA HIV1 VIRUSA NA 3 KLASE LIJEKOVA: PRVI SLUČAJ

Rezistencija virusa humane imunodeficijencije (HIV) na antiretrovirusne lijekove sprječava supresiju virusne replikacije te predstavlja značajan izazov u kliničkoj medicini. Posebno valja istaknuti problem primarne rezistencije (engl. transmitted drug resistance, TDR) koja se odnosi na prethodno neliječene osobe koje su zaražene rezistentnim sojevima HIV-a. Mutacije koje su povezane s primarnom rezistencijom (engl. transmitted drug resistant mutations, TDRM) su klinički značajne i mogu nepovoljno djelovati na učinkovitost antiretrovirusnog liječenja. U ovom je radu opisana prva osoba s primarnom rezistencijom HIV-a na 3 klase antiretrovirusnih lijekova u $\mathrm{Hr}$ vatskoj. Cilj ovog istraživanja bio je analizirati obrasce primarne rezistencije i TDRM u novodijagnosticiranog i neliječenog HIV-om zaraženog pojedinca. Primjenom Sangerovog sekvenciranja (SS) dokazali smo četiri mutacije povezane s rezistencijom na inhibitore reverzne transkriptaze (E44D, T215E, K103N, L100I) koje smanjuju osjetljivost na dvije klase lijekova (nukleozidne analoge inhibitore reverzne transkriptaze i nenukleozidne inhibitore reverzne transkriptaze) kao i dvije mutacije (V32I, I47V) povezane s rezistencijom na inhibitore proteaze. U svrhu identifikacije mogućeg postojanja manjinskih rezistentnih varijante ispod granice detekcije SS-a, provedena je analiza dubinskim sekvenciranjem (DS). DS analiza identificirala je isti obrazac rezistencije na 3 klase antiretrovirusnih lijekova identificiran s SS uz nekoliko dodatnih mutacija. U ovom je radu opisan prvi slučaj primarne rezistencije HIV-a na 3 klase antiretrovirusnih lijekova, a buduća istraživanja analizirat će moguće putove transmisije ovog rezistentnog virusa u Hrvatskoj.

KLJUČNE RIJEČI: HIV; primarna rezistencija; Sanger sekvenciranje (SS); dubinsko sekvenciranje (DS) 


\section{INTRODUCTION}

Highly active antiretroviral therapy (HAART) has had a tremendous impact on many individuals infected with Human Immunodeficiency Virus (HIV) and is the most important achievement in the history of HIV-therapy so far ${ }^{1}$.

Despite the wide use and benefit of antiretroviral drugs, the efficacy of HAART can be compromised by the emergence of drug resistance ${ }^{2}$. Resistance occurs as a result of mutations in the pol region of HIV genome coding for viral enzymes, reverse transcriptase, protease and integrase, that represent molecular targets of antiretroviral drugs ${ }^{3}$. Resistance of HIV to antiretroviral drugs is an important limitation to the suppression of viral replication and therefore represents an important clinical issue ${ }^{4}$. This issue refers especially to therapy-naive individuals infected with resistant HIV strains (transmitted drug resistance, TDR). Transmitted-drug resistance mutations (TDRMs) can persist significantly longer than acquired DRMs in infected persons, even in the absence of drug pressure ${ }^{5}$. That goes in favor of hypothesis that TDR is driven mainly by onward transmission from ART-naive individuals rather than from patients with a history of $\mathrm{ART}^{6-8}$. TDRMs may reduce the efficacy of antiretroviral therapy (ART), but genotypic resistance testing, performed before initiating treatment or after virologic failure, helps clinicians in choosing the right regimen and improves the efficacy of ART ${ }^{2}$.

To achieve the subsequent long-term treatment success, the resistance must be held under control by monitoring in both routine diagnostic setting and clinical research ${ }^{1,9}$.

Sanger sequencing has been the golden standard for characterization of HIV resistance so far, but with the development of new "deep sequencing" technologies and their increased sensitivity for detection of minor mutations, many clinical laboratories and research groups begun to implement it in their research ${ }^{10-14}$. With Sanger sequencing it is possible to detect viral quasispecies present in $15-20 \%$ of the total viral population while viral variants present in lower frequency will not be detected. On the other hand, deep sequencing allows analysis of viral minor variants represented in $<1 \%$ of the total population, which provides a new insight on pathogenesis of HIV-1 infection. The advantages of such sequencing are of exceptional importance because deep sequencing can help monitor the resistance while minor resistant variants are still in development and do not dominated the viral population ${ }^{10-14}$. The following groups of antiretroviral drugs are used for treatment of HIV-infection: nucleoside (NRTI) and non-nucleoside reverse transcriptase inhibitors (NNRTIs), protease inhibitors (PIs) and integrase inhibitors (INSTI). First-line ART consists of three or more antiretroviral drugs, usually two NRTIs in combination with one integrase inhibitor (recommended by the International AIDS Society-USA Guidelines, IAS-USA) ${ }^{2}$.

Croatia has a centralized system of care and universal free access to antiretroviral drugs for all HIV infected persons ${ }^{15}$. HAART is available since 1998 while the resistance testing is performed since $2005^{16}$. In this paper we report the first sampled case of transmitted triple-class, drug-resistant HIV-1 in Croatia in a treatment-naive newly-diagnosed patient.

MATERIALS AND METHODS

\section{HIV-1 genotyping}

Viral RNA was isolated from patient plasma using the QIAamp MinElute Virus Spin Kit (Qiagen, Hilden, Germany). HIV-1 genotyping was performed using an in-house HIV-1 genotyping assay with the BigDye Terminator v3.1 Cycle Sequencing Kit (Thermo Fisher Scientific, Dreieich, Germany) covering the protease (PR) and a part of reverse transcriptase (RT). Sequence analysis was performed on an ABI Prism 3500 capillary sequencer (Thermo Fisher Scientific, Germany). Vector NTI software (Thermo Fisher Scientific, Waltham, MA) was used to generate the consensus sequence and compare it with the reference strain HIV-1LAV-1 (GenBank number K02013). HIV-1 subtypes was assessed with the REGA HIV-1 subtyping tool Version 3.0.

Primary resistance to antiretroviral drugs was defined as the presence of $\geq 1$ mutation placed on the WHO surveillance for drug resistance mutations (SDRM) list ${ }^{17}$. Clinically relevant resistance to Nucleoside Reverse Transcriptase Inhibitors (NRTI), Non-Nucleoside Reverse Transcripase Inhibitors (NNRTI) or Protease Inhibitors (PI) was evaluated with IAS Drug Resistance Mutation list and Stanford University HIV Drug Resistance Database (HIVdb), Genotypic Resistance Interpretation Algorithm version 8.8 $8^{2,18}$

In addition, drug resistance result of HIVdb was compared to those of 2 other algorithms: Rega Institute and Agence Nationale de Recherches sur le SIDA (ANRS).

\section{Deep sequencing analysis}

To characterize HIV-1 minority drug resistance variants present at frequencies $(<10 \%)$ below the detection limit of Sanger sequencing, deep sequencing analysis was performed on the sample. The whole HIV-1 protease region and part of the reverse transcriptase region were sequenced with Illumina Miniseq (California, USA). After extraction, HIV-1 RNA was reverse transcribed with SuperScript ${ }^{\circ}$ III First-Strand Synthesis System for RT-PCR (Invitrogen, Carlsbad, CA) and UNINEF primer ${ }^{55}$. Amplification of the target region was done in 4 separate multiplex PCR reactions using ALLinTM Taq DNA Polymerase (highQu GmbH, UK). Viral DNA libraries were prepared for deep sequencing with NEBNext ${ }^{\circ}$ UltraTM II DNA Library Prep Kit for Illumina (New England BioLabs, MA, USA), according to the manufacturer's instructions. Sequencing was performed using MiniSeq MID output 300 cycles reagent kit (paired-end; 150+150). The sequencing data were further analysed with HyDRA Web (Government of Canada, Ottawa, Canada) with a 5\% sensitivity threshold ${ }^{19}$.

\section{Results}

\section{Patient characteristics}

In 2017, a 26 year old man was diganosed with HIV at the chronic stage of infection. HIV-1 subtyping showed that the patient was infected with subtype B. The route of HIV-transmission was sex with men. The patient had no previous exposure to therapy. Viral load at the time of diagnosis was $27400 \mathrm{HIV}-1$ RNA copies/ml of plasma.

\section{Sanger sequencing (SS)}

Sanger sequencing of the sample showed four RTI resistance mutations (E44D, T215E, K103N, L100I) affecting two drug classes (NRTI, NNRTI) and two PI resistance mutations (V32I, I47V) (Table 1).

When interpreting the results of genotipic resistance using three different algorithms, three levels of resistance were used: "S" (susceptible), "R" (resistant), and "I" (intermediate).

The results were considered consistent if all algorithms assigned the same level of resistance for the same drug. Complete divergence in the interpretation of the results was related to the case when one 
Table 1. Results of Sanger sequencing

\begin{tabular}{|c|c|c|}
\hline Drug Class & Mutations & $\begin{array}{c}\text { Resistance Interpretation } \\
\text { According to HIVdb }\end{array}$ \\
\hline NRTI & E44D, T215E & LLR: AZT \\
\hline NNRTI & K103N, L100I & $\begin{array}{c}\text { R: EFV, NVP, RPV } \\
\text { IR: DOR, ETR }\end{array}$ \\
\hline PI & V32I, I47V & IR: ATV $/ \mathrm{r}, \mathrm{DRV} / \mathrm{r}, \mathrm{LPV} / \mathrm{r}$ \\
\hline
\end{tabular}

NRTI- Nucleoside Reverse Transcriptase Inhibitors, NNRTI- Non-Nucleoside Reverse Transcripase Inhibitors, PI- Protease Inhibitors, AZT-zidovudine, EFV-efavirenz, NVP-nevirapine, RPV-rilpivirine, DOR-Doravirine, ETR-etravirine, ATV-atazanavir, DRV-darunavir, LPV-lopinavir, r-ritonavir, Mutation in bold-SDRM-Surveillance drug resistance mutations, LLR-low level resistance, $R$-resistance, IR-intermediate resistance

algorithm assigned the " $\mathrm{S}$ " and the other " $\mathrm{R}$ " level for the same drug. The interpretation of the algorithms was considered to be partially divergent if both "S" and "I" or "R" and "I" levels of resistance were assigned for the same drug. Complete divergence in the interpre

tation of genotipic resistance results was observed for doravirine of NNRTI drug class and darunavir and fosamprenavir of PI. CompariTable 2. Drug resistance interpretation according to three different algorithms analysis identified the triple class resistance with the same pattern that was identified by SS with addition of several other RTI mutations.

\section{Discusion}

The aim of this study was to characterize drug resistance patterns and TDRMs in the protease and reverse transcriptase-sequence of the first newly diagnosed/treatment naïve HIV-1 patient with triple class resistance from Croatia. Sanger sequencing identified triple class resistance to three antiretroviral drug classes (NRTIs, NNRTs and PIs).

\begin{tabular}{|c|c|c|c|c|c|}
\hline Drug classes & $\begin{array}{l}\text { Antiretroviral } \\
\text { Drugs }\end{array}$ & HIVDB & ANRS & REGA & \\
\hline \multirow{7}{*}{ NRTI } & ABAKAVIR & S & $\mathrm{S}$ & $\mathrm{S}$ & \\
\hline & ZIDOVUDIN & I & $\mathrm{R}$ & I & \\
\hline & STAVUDIN & I & $\mathrm{R}$ & I & \\
\hline & DIDANOZIN & S & S & S & \\
\hline & EMTRICITABIN & S & S & S & \\
\hline & LAMIVUDIN & S & S & S & \\
\hline & TENOFOVIR & S & S & S & \\
\hline \multirow{5}{*}{ NNRTI } & DORAVIRIN & I & $\mathrm{R}$ & S & \\
\hline & EFAVIRENz & $\mathrm{R}$ & $\mathrm{R}$ & $\mathrm{R}$ & \\
\hline & ETRAVIRIN & I & S & I & \\
\hline & NEVIRAPIN & $\mathrm{R}$ & $\mathrm{R}$ & $\mathrm{R}$ & \\
\hline & RILPIVIRIN & $\mathrm{R}$ & $\mathrm{R}$ & $\mathrm{R}$ & \\
\hline \multirow{7}{*}{ PI } & ATAZANAVIR/r & $\mathrm{I}$ & S & S & \\
\hline & DARUNAVIR/r & I & $\mathrm{R}$ & S & \\
\hline & $\begin{array}{l}\text { FOSAMPRENAVI } \\
\text { R/r }\end{array}$ & $\mathrm{R}$ & $\mathrm{R}$ & S & \multirow{5}{*}{$\begin{array}{l}\text { S-Susceptible, } \\
\text { I-Intermediate resistance, } \\
\text { R-Resistance } \\
\text { Yellow-consistent results, } \\
\text { Blue-partial divergence, } \\
\text { Red-complete divergence } \\
\text { r-ritonavir }\end{array}$} \\
\hline & INDINAVIR/r & I & S & S & \\
\hline & LOPINAVIR/r & S & $S$ & S & \\
\hline & SEKVINIIVIE/r & S & S & S & \\
\hline & TIPRANAVIR/r & I & S & I & \\
\hline
\end{tabular}

son of genotipic resistance algorithms is displayed in Table 2.

\section{Deep sequencing (DS)}

All mutation revealed by SS were also identified by deep sequencing. DS identified three additional RTI mutations (K101E, T215S, N348I) (Table 3).

Mutation concordance between the two platforms was partial. DS
In addition to Sanger sequencing, the patient sample was also analyzed by deep sequencing. The aim was to compare the results of two platforms and to investigate the use and benefit of DS in routine diagnostic.

HIV-1 infection in Croatia is primarily characterized by men who 
Original Article

Table 3. Comparison of SDRM detected with Sanger (SS) and deep sequencing (DS)

\begin{tabular}{|c|c|c|c|c|c|}
\hline Sample & $\begin{array}{c}\text { Mutation } \\
\text { concordance }\end{array}$ & $\begin{array}{c}\text { SS } \\
\text { SDRM }\end{array}$ & $\begin{array}{c}\text { DS } \\
\text { SDRM }\end{array}$ & $\begin{array}{c}\text { Frequency, } \\
\text { n }(\%)\end{array}$ & $\begin{array}{c}\text { Coverage, } \\
\text { number of reads }\end{array}$ \\
\hline 1378 & partial & $\begin{array}{c}\text { V32I, } \\
\text { I47V } \\
\text { L100I } \\
\text { K103N } \\
\text { T215E }\end{array}$ & $\begin{array}{c}\text { V32I } \\
\text { I47V } \\
\text { L100I } \\
\text { K103N } \\
\text { K101E } \\
\text { T215E } \\
\text { T215S } \\
\text { N348I }\end{array}$ & $\begin{array}{c}6.3 \\
43.1 \\
32.0 \\
32.6 \\
4.6 \\
38.3 \\
4.7 \\
23.6\end{array}$ & $\begin{array}{c}947 \\
288 \\
685 \\
682 \\
726 \\
5174 \\
5147 \\
236\end{array}$ \\
\hline
\end{tabular}

SDRM-Surveillance drug resistance mutations

have sex with men (MSM) who are mainly infected in Croatia ${ }^{20-21}$. Currently, HIV-infected persons are entering clinical care at early stages of infection (including acute and recent), but substantial proportion of patients are still enrolled into clinical care at the symptomatic stage of HIV-disease (late presenters). The patient described in this paper classifies as a late presenter to clinical care.

The prevalence of TDR in treatment-naive individuals remains stable in most developed countries and the prevalence of acquired drug resistance is decreasing ${ }^{22-29}$. This implies that further transmission of HIV-1 with TDRMs is occurring in ART-naive individuals $s^{6-8}$. The European SPREAD study, which included data for 25 European countries and Israel, showed an overall primary resistance prevalence of $8.4 \%$ (study period 2008 to 2010$)^{30}$.

The prevalence of primary HIV resistance to RT inhibitors in Croatia was one of the highest in the world (22\%) for the period 20062008 and was associated with a local cluster of MSM caring SDRM T215S ${ }^{31}$. While NNRTI associated mutations were present at low frequency, no primary resistance mutations related to PI were found during this period ${ }^{31}$. Results of a more recent study focusing on the period 2014-2017, showed the emergence of SDRM to NNRTI and PI as well as high overall prevalence of primary resistance (around $17 \%)^{32}$.

Besides T215 revertants (T215S being the most frequent) that are found common in untreated persons in Croatia, recent data suggested that triple class resistance patterns also contribute to the spread of resistant strains in Croatia as well. Triple class resistant variants, similar to those that have been described in the patient presented in this study, have been found to participate actively in the further spread of infection and primary resistance both locally and globally ${ }^{32}$.

Results of DS analysis partialy matched the results of Sanger sequencing. In addition, DS identified low-abundant viral variants with frequencies $<10 \%$ which were not detected by SS.

DS analysis showed that resistant variants responsible for initial infection could have gone under the radar of standard detection $(<15 \%)$ in late-presenters diagnosed in chronic stage of infection. The implementation of new tehnologies with already existing ones is especially usefull when dealing with complex clinical issues like this patient. This gives a new perspective and inside when choosing firstline treatment options.

Availability of more antiretroviral drugs as well as new drug classes has led to virological success even in patients with resistance but individuals with triple class resistance have

been associated with a higher risk of disease progression and death ${ }^{34-36}$. Therefore, the management of such patients is extremely challenging and the issue raises public health concerns because the resistant virus is likely to be spread widely. Early diagnosis and antiretroviral treatment of HIV-1 infections are therefore required to prevent the spread of drug-resistant HIV-1.

\section{AUtHOR CONTRIBUTIONS:}

All authors listed have made a substantial, direct and intellectual contribution to the work, and approved it for publication.

\section{LITERATURE:}

1. Volberding PA, Deeks SG. Antiretroviral therapy and management of HIV infection. Lancet. 2010; 376:49-62.

2. Günthard HF, Calvez V, Paredes R, Pillay D, Shafer RW, Wensing AM, Jacobsen DM, Richman DD. Human Immunodeficiency Virus Drug Resistance: 2018 recommendations of the international antiviral society-USA Panel. Clin Infect Dis. 2018.

3. TenoRes Study Group. Global epidemiology of drug resistance after failure of WHO recommended first-line regimens for adult HIV-1 infection: a multicentre retrospective cohort study. Lancet Infect Dis. 2016; 16:565-75.

4. De Luca A. The impact of resistance on viral fitness and its clinical implications. In: Geretti AM, editor. Antiretroviral Resistance in Clinical Practice. London. 2006.

5. Machnowska P, Meixenberger K, Schmidt D, IJessen H, Hillenbrand H, Gunsenheimer-Bartmeyer B, Hamouda O, Kucherer C, Bannert N, the German HIV-1 Seroconverter Study Group. Prevalence and persistence of transmitted drug resistance mutations in the German HIV-1 Seroconverter Study Cohort. PLOS ONE, 2019; https://doi.org/10.1371/journal.pone.0209605.

6. Pouran Yousef K, Meixenberger K, Smith MR, Somogyi S, Gromoller S, Schmidt D, et al. Inferring HIV-1 Transmission Dy- namics in Germany From Recently Transmitted Viruses. J Acquir Immune Defic Syndr. 2016; 73(3):356-63.

7. Hauser A, Hofmann A, Hanke K, Bremer V, Bartmeyer B, Kuecherer C, et al. National molecular surveillance of recently acquired HIV infections in Germany, 2013 to 2014. Euro Surveill. 2017; 22(2).

8. De Luca A, Zazzi M. Interplay Between Transmitted and Acquired HIV Type 1 Drug Resistance: Reasons for a Disconnect. J Infect Dis. 2015; 212(1):5-7.

9. Cossarini F, Spagnuolo V, Gianotti N, Carbone A, Lazzarin

A, Castagna A. Management of HIV infection after triple class failure.. New Microbiologica. 2012; 36: 23-39.

10. Messiaen P, Verhofstede C, Vandenbroucke I, Dinakis S, Van Eygen V, Thys K, Winters B, Aerssens J, Vogelaers D, Stuyver LJ, Vandekerckhove L. Ultra-deep sequencing of HIV-1 reverse transcriptase before start of an NNRTI-based regimen in treatment-naive patients. Virology. 2012; 426(1):7-11.

11. Ekici H, Rao SD, Sönnerborg A, Ramprasad VL, Gupta R, Neogi U. Cost-efficient HIV-1 drug resistance surveillance using multiplexed high-throughput amplicon sequencing: implications for use in low- and middle-income countries. J Antimicrob 
Chemother. 2014; 69(12):3349-55.

12. Kijak GH, Sanders-Buell E, Harbolick EA, Pham P, Chenine AL, Eller LA, Rono K, Robb ML, Michael NL, Kim JH, Tovanabutra S. Targeted deep sequencing of HIV-1 using the IonTorrentPGM platform. J Virol Methods. 2014; 205:7-16.

13. Casadellà M, Paredes R. Deep sequencing for HIV-1 clinical management. Virus Res. 2017 Jul 2. Alidjinou EK, Deldalle J, Hallaert C, Robineau O, Ajana F, Choisy P, Hober D, Bocket L. RNA and DNA Sanger sequencing versus next-generation sequencing for HIV-1 drug resistance testing in treatment-naive patients. J Antimicrob Chemother. 2017; 72(10):2823-2830. 14. Trabaud MA, Icard V, Ramière C, Tardy JC, Scholtes C, André P. Comparison of HIV-1 drug-resistance genotyping by ultra-deep sequencing and sanger sequencing using clinical samples. J Med Virol. 2017; 89(11):1912-1919.

15. Croatian National Institute of Public Health. (http://www. hzjz.hr/epidemiologija/hiv.htm) (Accessed October 2019) 16. Begovac J, Zekan A, Skoko-Poljak D. Twenty years of human immunodeficiency virus infection in Croatia-an epidemic that is still in an early stage. Coll Antropol 2006; 30:17-23.

17. Bennett, DE et al. Drug resistance mutations for surveillance of transmitted HIV-1 drug-resistance: 2009 update. PLoS One. 2009; 4: e4724. DOI: 10.1371/journal.pone.0004724,

18. Stanford University HIV Drug Resistance Database. Available at, http://hivdb.stanford.edu/DR/ (Accessed, October, 2019). 19. HyDRA Web. Analyze Next Generation Sequencing data for HIV Drug Resistance. Available at, https://hydra.canada.ca/ pages/home?lang=en-CA, (Accessed, June 2019).

20. Bozicevic, I, Begovac, J. The emerging HIV epidemic among men who have sex with men in southeastern Europe. Expert. Rev. Anti. Infect. Ther. 8, 2010; 1351-1358.

21. Bozicevic, I et al. Prevalence of HIV and sexually transmitted infections and patterns of recent HIV testing among men who have sex with men in Zagreb, Croatia. Sex. Transm. Infect. 2012; 88:539-544.

22. Pineda-Pena AC, Schrooten Y, Vinken L, Ferreira F, Li G, Trovao NS, et al. Trends and predictors of transmitted drug resistance (TDR) and clusters with TDR in a local Belgian HIV-1 epidemic. PLoS One. 2014; 9(7):e101738.

23. Yang WL, Kouyos R, Scherrer AU, Boni J, Shah C, Yerly S, et al. Assessing the Paradox Between Transmitted and Acquired HIV Type 1 Drug Resistance Mutations in the Swiss HIV Cohort Study From 1998 to 2012. J Infect Dis. 2015; 212(1):28-38. 24. Mourad R, Chevennet F, Dunn DT, Fearnhill E, Delpech V, Asboe D, et al. A phylotype-based analysis highlights the role of drug-naive HIV-positive individuals in the transmission of antiretroviral resistance in the UK. AIDS. 2015; 29(15):1917-25. 25. Parczewski M, Leszczyszyn-Pynka M, Witak-Jedra M, Maciejewska K, Rymer W, Szymczak A, et al. Transmitted HIV drug resistance in antiretroviral-treatment-naive patients from Poland differs by transmission category and subtype. J Antimicrob Chemother. 2015; 70(1):233-42.

26. Ambrosioni J, Sued O, Nicolas D, Parera M, Lopez-Dieguez
M, Romero A, et al. Trends in Transmission of Drug Resistance and Prevalence of Non-B Subtypes in Patients with Acute or Recent HIV-1 Infection in Barcelona in the Last 16 Years (19972012). PLoS One. 2015; 10(6):e0125837.

27. Schmidt D, Kollan C, Fatkenheuer G, Schulter E, Stellbrink HJ, Noah C, et al. Estimating trends in the proportion of transmitted and acquired HIV drug resistance in a long term observational cohort in Germany. PLoS One. 2014; 9(8):e10447 28. Paraskevis D, Kostaki E, Magiorkinis G, Gargalianos P, Xylomenos G, Magiorkinis E, et al. Prevalence of drug resistance among HIV-1 treatment-naive patients in Greece during 20032015: Transmitted drug resistance is due to onward transmissions. Infect Genet Evol. 2017; 54:183-91.

29. Bezemer D, van Sighem A, Lukashov VV, van der Hoek L, Back N, Schuurman R, et al. Transmission networks of HIV-1 among men having sex with men in the Netherlands. AIDS. 2010; 24(2):271-82.

30. Vercauteren J, Wensing AM, van de Vijver DA, Albert J, Balotta C, Hamouda O, Kucherer C, Struck D, Schmit JC, Asjo B, Bruckova M, Camacho RJ, Clotet B, Coughlan S, Grossman Z, Horban A, Korn K, Kostrikis L, Nielsen C, Paraskevis D, Poljak M, Puchhammer-Stockl E, Riva C, Ruiz L, Salminen M, Schuurman R, Sonnerborg A, Stanekova D, Stanojevic M, Vandamme AM, Boucher CA. Transmission of drug-resistant HIV-1 is stabilizing in Europe. J Infect Dis. 2009; 200:1503-1508. 31. Grgic I, Zidovec Lepej S, Lunar MM, Poljak M, Vince A, Vrakela IB, Planinic A, Seme K, Begovac J. The prevalence of transmitted drug resistance in newly diagnosed HIV-infected individuals in Croatia: the role of transmission clusters of men who have sex with men carrying the T215S surveillance drug resistance mutation. AIDS Res Hum Retroviruses. 2013; 29:329-336. 32. Oroz M, Planinic A, Begovac J, Židovec-Lepej S. High prevalence of transmitted HIV drug resistance mutations in a cohort of newly diagnosed HIV-infected patients at entrance to care in the period from 201 to 2015: The Croatian data. Abstract presented at 16th European Meeting on HIV \& Hepatitis 2018, May 30June 1, Rome, Italy.

33. Zaccarelli M, Tozzi V, Lorenzini P, Trotta MP, Forbici F, Visco-Comandini U, Gori C, et al.

Multiple drug class-wide resistance associated with poorer survival after treatment failure in a cohort of HIV-infected patients. AIDS (London, England). 2005;19 (10):1081-1089.

34. Grover D, Copas A, Green H, Edwards SG, Dunn DT, Sabin C, Phillips A, Allen E, Pillay D and UK collaborative group on hiv drug resistanceand uk collaborative hiv cohort study. What is the risk of mortality following diagnosis of multidrug-resistant HIV-1? The Journal of Antimicrobial Chemotherapy. 2008; 61(3):705-713.

35. Di Giambenedetto S, Colafigli M, Pinnetti C, Bacarelli A, Cingolani A, Tamburrini E, Cauda R, De Luca A. Genotypic resistance profile and clinical progression of treatment-experienced HIV type 1-infected patients with virological failure. AIDS Research and Human Retroviruses. 2008; 24(2):149-154. 